\title{
Poverty alleviation, conflict and power in poor displaced households: A study of the views of women in Diyarbakır
}

Department of History, Leyla Şen

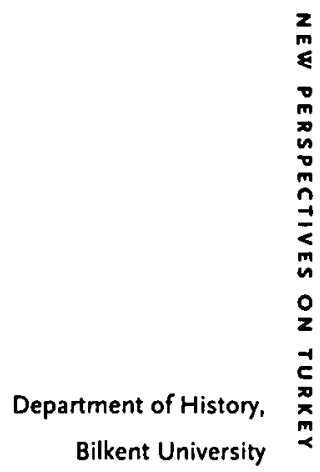

\section{Introduction}

According to official data, urban poverty has been rising in Turkey since the 1990s. ${ }^{1}$ Macro-level causes include repetitive economic crises, the implementation of neoliberal policies recommended by international financial organizations, the failure to create employment and the increasing inequality in income distribution. The intensity of poverty in different provinces is related to the specific conditions of a particular region. In the 1990 s, there was an influx of internally displaced people (IDPs) into the cities of Southeast Anatolia. The lack of employment opportunities, the state's reluctance to address the problems of IDPs and the IDPs' loss of kinship/community networks contributed to the deterioration of their condition in the new urban setting. ${ }^{2}$

This essay examines the dynamics among women in displaced households in the new urban context. The mobilization of female labor as one solution for household survival in the city leads to conflicting dynamics within the household. My interviews ${ }^{3}$ with women revealed that mobilized young female labor faces conflict with and opposition from not only men, but also from the adult women in the household. Confrontations between male family members and workingwomen, regardless of the women's age, are highly related to expected gender roles and a fear of losing dominance. Older women's attitude towards younger

Author's note: I would like to thank Assoc. Prof. Ahmet Saltık, who provided helpful comments on the first draft of this essay, and the editors of New Perspectives on Turkey for their comments on earlier versions.

12002 Yill Hanehalkı Bütçe Anketi, (Ankara: State Institute of Statistics, 2003), 2003 Yilı Hanehalkı Bütçe Anketi, (Ankara: State Institute of Statistics, 2004).

2 Sema Erder, "Yeni Kentliler ve Kentin Yeni Yoksulları," Toplum ve Bilim, no. 66 (1995), Melih Ersoy and H. Tarık Şengül, Kente Góf ve Yoksulluk: Diparbakır Orneği (Ankara: ODTÜ Kentsel Politika Planlaması ve Yerel Yönetimler Anabilim Dalı Yayınları, 2002).

3 The data for this essay was taken from a field research I conducted in Diyarbakır in 1998 as part of a report submitted to the South East Regional Development Administration. 
workingwomen is also related to the loss of authority and status that these older women are granted under the prevailing patriarchal system.

Contrary to claims that working outside of home is universally beneficial for women, my fieldwork showed that in the case of Diyarbakır, in fact, the situation of young workingwomen is worsened by the reproduction of patriarchy by older women in response to the perceived challenge to their own limited power that young workingwomen pose. While the income derived from workingwomen increases the overall resources of the household, it does not automatically lead to equitable control and use of these resources. On the contrary, the increased income may increase the wealth and power gaps within the household. The young workingwomen in Diyarbakır have no control over their earnings and do not participate in decisionmaking processes. Furthermore, their behavior comes under increased control of other family members.

The relationship between younger workingwomen and older women in the household demonstrates that women are not a homogenous group, and that differences in their expectations and positions within the household leads to conflicting dynamics among them. ${ }^{4}$ These dynamics need to be taken into consideration in the formulation of context-specific poverty mitigation/alleviation schemes, which must specifically address the needs and expectations of the different household members, who have conflicting interests, regardless of gender.

\section{Household dynamics, poverty and gender in patriarchal households}

Substantive advances have been achieved towards the conceptualization of the household by "bargaining models," among them, the model of "cooperative conflict" put forward by Amartya Sen. In his conceptualization of the household as an arena of "cooperative conflict," Sen argues that household members co-operate with each other despite their conflicting interests because they benefit more from the outcomes of co-operation than non-cooperation. Sen's model also examines the role of perceptions - perceptions of both interests (of the concerned individual) and contributions (of others). He also stresses the links between perceptions, wellbeing (in the sense of achieved "functionings," i.e., various things a person may value doing or being) and agency (a person's ability to achieve, within his or her social context, those things that he or she values). ${ }^{5}$ This perspective allow.s for the analysis of household

4 Deniz Kandiyoti, Cariyeler, Bacilar, Yurttaşlar (Istanbul: Metis, 1997), Jenny B. White, Money Makes Us Relatives: Women's Labor in Urban Turkey (Texas: University of Texas Press, 1994).

5 Amartya Sen, "Gender and Cooperative Conflicts," in Persistent Inequalities, ed. Irene Tinker (Oxford: Oxford University Press, 1990). 
differentiation along gender and age axis and is the perspective employed by this study in analyzing the situation of women in poor displaced households.

In patriarchal societies, men place restrictions on the activities of women. By blocking their access to various resources, including land, credit, the labor market, education and healthcare, men actively create women's poverty. While various studies have been conducted on these patriarchal practices, ${ }^{6}$ there appears to be little interest in the dynamics among women in patriarchal households. Apart from reports on the conflicting nature of relationships between older women and younger married women, ${ }^{7}$ existing studies create the impression that solidarity between female household members is the norm. However, this study challenges this latter assumption.

In the OECD definition of poverty, the household, rather than the individual, is the focus. According to the OECD, poverty encompasses "different dimensions of deprivation that relate to human capabilities including consumption and food security, health, education, rights, voice, security, dignity and decent work."8 Household-focused research has stressed the relevance of understanding household structure, the domestic cycle and power relationships among household members. When faced with poverty, households respond to the socio-economic possibilities and resist the constraints through a series of coping endeavors known as "survival strategies." The course of the survival strategy is determined by the assets and structure of each household.$^{10}$ This explains the diversity of strategies - for example, reducing consumption, increasing debt, liquidating property, using kinship/social networks, and mobilizing available assets adopted within the same overall context. The majority of research on the

6 Claudia Buchmann, "Family Structure, Parental Perceptions and Child Labor in Kenya: What Factors Determine Who is Enrolled in School?" Social Forces 78, no. 4 (2000), Shelley Feldman, "Exploring Theories of Patriarchy: A Perspective from Contemporary Bangladesh," Journal of Women in Culture and Society 26, no. 4 (2001), Christina E.E. Okojie, "Women in the Rural Economy in Nigeria," in Women, Work and Gender Relations in Developing Countries: A Clobal Perspective, ed. Parvin Ghorayshi and Claire Belanger (Connecticut \& London: Greenwood Press, 1996), Sylvia Walby, Patriarchy at Work (Cambridge: Polity, 1986).

7 Sylvia Chant, Women and Sunvival in Mexican Cities (Manchester: Manchester University Press, 1991), Deniz Kandiyoti, "Bargaining with Patriarchy," Gender \& Society 2, no. 3 (1998), Nükhet Sirman, "The Constitution of Relations between Strangers in Turkey" (paper presented at the SSRC the Beirut Conference on Public Spheres, 22-24 October 2004).

8 OECD, DAC Guidelines on Poverty Reduction (Paris: 2001), 8.

9 Mercedes De la Rocha and Alejandro Grinspun, "Private Adjustments: Household, Crisis and Work," in Choices for the Poor. Lessons from National Poverty Strategies, ed. Alejandro Grinspun (UNDP, 2001), Caroline Moser, "Asset Vulnerability Framework: Reassessing Urban Poverty Reduction . Strategies," World Development 26, no. 1 (1998).

10 Chant, Women and Survival in Mexican Cities. 
impact of these strategies on intra-household dynamics focuses on the nature of these strategies and the resulting patriarchal practices. ${ }^{11}$ For most poor families, human labor represents the only asset, and the predominant strategy is to increase the number of working hours of those already working and to mobilize female and child labor. ${ }^{12}$

There is a growing body of scholarship on the issue of poverty in Turkey. Numerous studies have examined the intra-household dynamics of poor urban households and described the mobilization of female and child labor as an important survival strategy. ${ }^{13}$ These studies also note the diversity of attitudes in poor urban households towards female labor mobilization. ${ }^{14}$ The findings of these studies note that although women in rural migrant families generally approve of female employment, ${ }^{15}$ men disapprove, citing concern for the women's honor as the reason. ${ }^{16}$ Several studies have scrutinized the impact of labor market involvement on women's lives. Some studies point to a correlation between persisting patriarchal norms and an unequal intra-household distribution of resources as well as an increased pressure on the mobilized female labor force. ${ }^{17}$ Again, several authors note that in spite of this increased pressure, the mobilized female labor is able to develop resistance strategies "within the boundaries of patriarchal arrangements." 18 In studies of workingwomen elsewhere in the world, some authors have argued that young women gain a bargaining position in the family, control over their earnings and some say in choosing

11 Buchmann, "Family Structure, Parental Perceptions and Child Labor in Kenya.", De la Rocha and Crinspun, "Private Adjustments.", Feldman, "Exploring Theories of Patriarchy."

12 De la Rocha and Grinspun, "Private Adjustments.", Moser, "Asset Vulnerability Framework."

13 Istiklal Alpar and Samira Yener, Gecekondu Araștırması (Ankara: The Directorate of Social Planning Publication, 1991), Ümit Onat, Gecekondu Kadınının Kente Ozgü Düsünce ve Davranışlar Geliştirme Süreci (Ankara: Başbakanlık Kadın ve Sosyal Hizmetler Müsteşarlığı Yayınları, 1993), Cezmi Sevgi. Kentleşme Sürecinde izmir ve Gecekondular (Izmir: İzmir Konak Belediyesi Kültür Hizmetleri, 1988), Tansı Şenyapılı, Gecekondu: Çevre Iş̧̧lerin Mekanı (Ankara: Middle East Technical University, 1981).

14 Tahire Erman, Sibel Kalaycıoğlu, and Helga Tilsç-Rittersberger, "Money Earning Activities and Empowerment of Rural Migrant Women in the City: The Case of Turkey," Women's Studies International forum 25, no. 4 (2002), Birsen Gökçe, ed., Gecekondularda Ailelerarası Celeneksel Dayanışmanın Çağdaş Organizasyonlara Dönüşümü (Ankara: Başbakanlık Kadın ve Sosyal Hizmetler Müsteşarlığı Yayını, 1993), Sibel Kalaycıoğlu and Helga Tılıç-Rittersberger, Evimizdeki Cündelikçi Kadinlar (istanbul: Su Yayınları, 2001).

15 Kalaycıoğlu and Tilı̨̧-Rittersberger, Evimizdeki Cündelikģi Kadınlar.

16 Mine Çınar, "Unskilled Urban Migrant Women and Disguised Employment: Home-Workingwomen in Istanbul, Turkey," World Development 22, no. 3 (1994), Kalaycioğlu and Tilı̧-Rittersberger, Evimizdeki Cündelikģi Kadınlar.

17 Kalaycıoğlu and Tilıç-Rittersberger, Evimizdeki Gündelikçi Kadınlar.

18 Hale C. Bolak, "Marital Power Dynamics: Women Providers and Working-Class Households in Istanbul," in Cities in the Developing World, ed. Josef Gugler (New York: Oxford University Press, 1997), Nükhet Sirman, "Friend and Foe? Forging Alliances with Other Women in a Village of Western Turkey," in Women in Modern Turkish Socieţ: A Reader, ed. Şirin Tekeli (New Jersey: Zed, 1995). 
their spouses. ${ }^{19}$ In contrast, the findings of my fieldwork show that workingwomen in Diyarbakır face increased control from their families, relatives and communities. Furthermore, cooperation and solidarity between non-employed older women and young male household members supports the subjugation of younger workingwomen.

This essay aims to show how the relationships between women in displaced households affect the possibilities for empowerment of the workingwomen in terms of access to and control over resources and participation in decision-making processes. When mothers cooperate with their working daughters and attempt to mediate between the male household members and these workingwomen, then the bargaining and negotiating power of the daughters improve. When, on the other hand, conflict rather than co-operation dominates, the situations of the daughters worsen.

\section{Background: IDPs in Diyarbakır}

The UN defines IDPs as "persons or groups of persons who have been forced or obliged to flee or to leave their homes or places of habitual residence, in particular as a result of or in order to avoid the effects of armed conflict, situations of generalized violence, violations of human rights or natural or human-made disasters, and who have not crossed an internationally recognized state border." ${ }^{20}$ In Turkey, from 1985 to 1999, population displacements took place specifically in relation to the activities of the Kurdistan Workers' Party (PKK) and the Turkish Government's counter-insurgency operations in the southeast. Almost all of the IDPs in the region were ethnic Kurds, and the reason for their displacement were either pressure from the PKK or state authorities, or economic necessity resulting from a severe reduction in income, itself an outcome of the restrictive measures implemented in the region. ${ }^{21}$ The current number of IDPs in Turkey is a matter of contention. According to figures provided by the Emergency Rule Governorship, a total of 387,000 people were internally displaced during the early 1990 s, as a result of either evacuation of villages by the state or voluntary movement. ${ }^{22}$ NGO estimates are much higher, ranging from one to three million. ${ }^{23}$ Between 1990 and 1996, the

19 Aihwa Ong, Spirits of Resistance and Capitalist Discipline: Factory Women in Malaysio (Albany: State University of New York Press, 1987), Diane Wolf, Factory Daughters: Cender, Household Dynamics and Rural Industrialization in Java (Berkeley: University of California Press, 1992).

20 UN, Guiding Principles on Internal Displacement (New York: 1998).

21 Ahmet Türkyılmaz et al., Doğu ve Güneydoğu Anadolu'dan Terör Nedeniple Göf̧eden Ailelerin Sorunlan (Ankara: Başbakanlık Aile Araştıma Kurumu Başkanlı̌̆ı Yayınları No 115, 1998), 3.

22 Ibid., 67.

23 For instance, Göç-Der, Gö̧ Edenlerin Sospo-Ekonomik, Sospo-Kültürel Durumlan, Göçün Ortaya 
population of Diyarbakır increased from 381,000 to more than 800,000 people as a result of these displacements. ${ }^{24}$

In contrast to the voluntary character of earlier migration waves shaped by push-pull factors, the population movement of the 1990 s was "sudden," "massive" and "forced." 25 Unlike migrant families of previous generations, who often sent a pioneering male member of the household to find a job and arrange accommodation for the family in the area of future settlement, the families displaced in the 1990s did not enjoy a transition period; rather, they were completely and suddenly cut off from their villages and from food supplies stockpiled at home, a resource crucial for their survival. ${ }^{26}$

Within the dynamics of internal migration, internal displacement is a significant factor that is not referred to in the majority of research on the issue. Moreover, the limited literature available on IDPs does not address intra-household dynamics, ${ }^{27}$ nor does it examine the experiences of displaced women. Small-scale field research has revealed that women displaced in the 1990s face more complicated problems and are more negatively affected by the displacement process than women who migrated to the cities in the previous waves. Barut argues that in the new context, women, together with children, comprise the "most vulnerable" group. ${ }^{28}$ However, a detailed analysis of the real situation of the displaced women is lacking. This study aims to shift the focus from a generalized description of IDPs to focus on women, showing how displacement negatively affects the relationships among women in the household in the urban context.

My fieldwork focused on IDPs from villages of Lice, Çınar, Dicle, Kulp, Hani, Hazro and Silvan townships who settled in two locations in the Seyrantepe district of Diyarbakır. As a result of displacement, the population of Seyrantepe dramatically increased from 5,406 in 1990 to 33,470 in $2000 .^{29}$ "500 Evler" housing complex was specifically

Çıkardığı Sorunlar, Askeri Çatışma ve Cerginlik Politikası Sonucu Yaşam Alanlann Terk Eden Cǫ̧̈ Mağdurlannın Geri Dönüş Eğilimi Araştırması (İstanbul: 1999-2001).

24 Rıfat Dağ, Atilla Göktürk, and H. Cengiz Türksoy, eds., Bölgeiçi Zorunlu Goçten Kaynaklanan Toplumsal Sorunların Diparbakır Kenti Olçeğinde Araştırılması (Ankara: TMMOB Yayınları, 1998), Ersoy and Şengül, Kente Cöç ve Yoksulluk: Diyarbakır Orneği.

25 Sema Erder, "Köysüz 'Köylü' Göçü," Görüs, no. 34 (1998).

26 Ibid.

27 Dağg, Göktürk, and Türksoy, eds., Bölgeiçi Zorunlu Gö̧̧, Ersoy and Şengül, Kente Göç ve Yoksulluk: Diyarbakır Ormeği, Atilla Cöktürk, "Zorunlu Göç ve Bir Kent: Diyarbakır," in II. Ulusal Sosyoloji Kongresi: Toplum ve Cö̧́ (Ankara: Sosyoloji Derneği Yayın No: 5, 1997).

28 Mehmet Barut, "Çocuk ve Kadın Boyutuyla Göçün Sosyolojik Açıdan Değerlendirilmesi," in Gö̧̧ Konferansı (Istanbul: Kırmızı Reklam Yayıncilık, 2004), Ipek Ilkkaracan, "Göç, Kadının Ekonomik Konumu ve Karar Mekanizmalar," iktisat Dergisi, no. 377 (1998).

Ersoy and Şengül, Kente Cö̧̧ ve Yoksulluk: Diyarbakır Ömeği, 174. 
constructed to house IDPs; "450 Evler," antoher housing complex, on the other hand, was originally built in the late 1970s to shelter the survivors from the Lice-Kulp earthquake, but had remained empty until 1988 when the refugees from Northern Iraq were settled there. After the Iraqis' departure, 450 Evler received the displaced families from the rural areas of the region. ${ }^{30}$

Pervasive poverty, unemployment and underemployment are common features in 500 Evler and 450 Evler. These problems are not peculiar to these two settlements, but are endemic among IDPs in general. The massive population increase in Diyarbakır in the first half of the 1990s was paralleled by a six-fold increase in unemployment. By 1998 , more than 70 percent of Diyarbakır's population of working age was unemployed. ${ }^{31}$ In 1996, 67 percent of the jobseekers in the city were from families of the post-1990 displacement. Only 24.43 percent of those actively working in these households were regularly employed. Not surprisingly, 81.1 percent of internally displaced households defined unemployment as the main problem they faced in the urban setting. ${ }^{32}$

The combination of the massive influx of people and subsequent unemployment resulted in widespread poverty throughout the city. According to a study conducted in 1997, per capita income in Diyarbakır was USD 283 overall and USD 203 for IDPs, whereas a UN-supported study set the poverty line in Turkey in 1997 as USD 380. In other words, 87.8 percent of the population of Diyarbakır and 95.2 percent of IDPs in the city lived below the poverty line. Accordingly, internally displaced families said they had been much better off socio-economically before displacement. ${ }^{33}$

\section{"Poverty" and "exclusion" in the words of women}

I collected the data for this study through semi-structured interviews with 30 women in 500 Evler and 450 Evler in Diyarbakır in the summer of 1998. The interviewees included two groups, 21 married women and nine young single women, all of whom were Kurdish. Two of the married women were under 25 , and the rest were between 30 and 40 ; two older women aged sixty were also interviewed. The majority of the married women had four or more children. Five of them were literate, but only two had completed primary school. All of them defined themselves as

30 TKV, "Unpublished Household-Level Survey among Migrant Families in Diyarbakır," (1996).

31 Dağ, Cöktürk, and Türksoy, eds., Bölgeiçi Zorunlu Cö̧̧, Ahmet Ozer, "Güneydoğu'da Kentleşeme(me) Dramı," Görüş, no. 34 (1998), 36.

32 Dağ, Gơktürk, and Türksoy, eds., Bölgeiçi Zonunlu Gọ̧̈.

33 Ozer, "Cüneydoğu'da Kentleşeme(me) Dramı," 36. 
housewives, but they were willing to do irregular work such as cleaning houses, although only four were working at the time of my interviews. The younger women were between the ages of 15 and 19, all of them were literate, and all of them were fluent in both Turkish and Kurdish. All of the younger women had begun to participate in the labor market after their migration to the city.

The adult female members of the households perceived the city as a hostile world in which they had been forced to settle. When asked if they would have left their homes and moved to the city had there not been serious conflict in the region, all the interviewed women said they would not have done so. More than half of these women said that before they had migrated, nearly all the young men used to move temporarily from their villages to the big cities in order to work, but that this had not affected the household in the way that displacement did. The women complained that the structure of the urban environment was alien to their previous pastoral lifestyles. In the city, to a great extent, they lacked social and kinship networks. Without support, their vulnerability intensified, thus leading to their exclusion and isolation in the city.

The unskilled labor force of Diyarbakır did not welcome the IDPs, since their settlement in the area increased the labor pool and consequently lowered wages. Employment could only be found in the informal sector, ${ }^{34}$ where the lack of permanent job opportunities denied the families a regular income. Because their dependence on money was far greater in the city than in the rural areas, this presented an immense challenge to their ability to survive.

The inadequacy of financial resources affects all aspects of women's lives and increases the pressure on them, since they are expected to make sacrifices. The sacrifices female members make are experienced at different degrees depending on the household structure; nevertheless, hardly any female member escapes some form of sacrifice. For instance, regardless of the inner dynamics in each household, the adult women and the eldest daughters have less access to food and to such basic necessities as health services. The women interviewed stated that due to the deteriorating living conditions in the urban areas, they did not have the opportunity to go to healthcare units. Ironically, in spite of the fact that they have become physically closer to healthcare services, they are increasingly isolated from them financially and psychologically, and are only able to access them in an emergency.

34 Sencer Ayata, Kentsel Enformal Sektörde istihdam ve iş Potansiyelinin Celiştirilmesi: Diyarbakır Alan Araştırması (UNDP, 2002). 
Kadriye, 39 and mother of five children, tried to adapt to these new conditions. She explained the increased importance of money in her life: "In the village, I did not know the value of money. Here I learned that five million is worth more than one million. I had to learn; otherwise people would cheat me." The household's increased dependency on cash in the urban context is also a source of misery for the young workingwomen. Sultan, 18, commented: "in the village we did not worry about money. We could prepare our meals and continue daily activities without money... But here you know that money is the sole means of survival."

The increased dependence on money for essential food purchases in the city contrasts with life in the rural areas, where households were able to produce basic foods for their own consumption. This, in turn, has had a major impact on the dynamics of the households regarding consumption patterns, the status of adult women and access to available resources. Remziye, 32, mother of three girls and two sons between the ages of five and fourteen stated that she and her daughters "are the last ones to eat. My eldest daughter and I give priority to the younger girls, and then we eat what remains in the bowl." The young workingwomen also experienced a similar change in consumption as a direct result of poverty. Kader, a young workingwoman, explained: "In the village, my mother, my sisters and I ate together after the men, but I don't recall leaving the table hungry. There was enough food for all of us. Here, my mother and I eat last, and we always leave the table hungry." Among the men, the most fortunate were the boys, whereas among the women, the elderly were usually the "luckiest." The women explained how the elderly were encouraged to consume more milk and yoghurt. Şemsen, 34, stated: "I feel sorry when I see my mother silently weeping... I give her the largest portion of yoghurt, which is her favorite. I do not want her to forget the taste of yoghurt."

Several interviews revealed that negative trends in consumption patterns posed a direct challenge to the women's traditional role as caretakers. Zilan, 33, commented sadly: "In the village, I prepared the basic food items without asking anyone. Here, even for just a small bit of food, 1 have to wait for my husband and ask him for money to buy food. If there were no children, I would prefer to remain hungry rather than listen to his humiliating responses." Instead of criticizing men for their inadequate earnings, some members of the family blamed the women for being unable to feed their children.

In the increasing poverty of the urban context, women - both older non-working women and young workingwomen - experienced greater oppressive behavior and violence from the men in the family. Kadriye 
commented on her husband of 24 years: "I would not dare to ask for anything unless he began the conversation. The children go to bed early to escape from his shouting." In this community, talking about domestic violence and divorce is rarely tolerated; women feel they must bear all difficulties without any complaints. In the words of Kadriye and Gülsün: "These are our husbands. This is God's will. These are the days that we must bear." The young workingwomen generally complained about the overall deterioration in interpersonal relationships within the family. As Zekiye stated, "in this community there is a lot of violence, and as the young unmarried women of the community, we receive a larger share than anybody else."

Roksan, an older non-working woman, confirmed this view. Pointing to the increasing tension within the household, she stated: "I feel that everything is changing. We are not the same family we were in the village. My husband has a world of his own, asking for money, smoking and speaking little. When he is angry, the house turns into hell. I do not have any idea where my children are, who their friends are in the city. They do not even answer a simple question about their lives. We were a family in the past ... now I do not know what will happen to us."

Although the reduction in consumption as one of the major experiences of poverty affects both the young workingwomen and the older nonworking women, it is perhaps more difficult for those women who are used to managing the household. Roj had to take care of eight people - her four children, husband, parents-in-law and a single sister-in-law - and pointed out that despite working "very hard and for very long hours [in the village], I was happy. My husband respected me, my parents-in-law were proud of the outcomes of my work in the field and the house. I could feed my children. What do I have here? Nothing!"

Among the IDPs interviewed, the reduction of expenses and increased restriction on some household members' access to basic resources were the immediate responses against poverty. However, as the women explained, these were insufficient for ensuring permanent safety and well-being in the future, but were merely able to preserve the household on a short-term basis. Cemile, a 40-year-old woman with five children, emphasized that "the only solution is to have a regular income." But most of these families cannot hope to have a regular income; the best alternative for them is to mobilize the available household "assets," particularly female and child labor.

\section{Changes in women's roles and household dynamics in IDP coimmunities}

The mobilization of the female labor force in displaced households in 
Diyarbakır is a response to poverty that can be witnessed in many poor communities, as documented in numerous studies. ${ }^{35}$ However, the household dynamics surrounding the employment of young women might show great variance. In my interviews with women in Diyarbakır it became clear that the young women did not actively choose to work; rather, the male household members decided on the mobilization of female labor. Although the immediate reaction of men to the idea of women working was prohibition, their resolve weakened as the difficulties in meeting basic household necessities increased. Berfin, 33, gave an example of this:

When we first arrived in the city, I could not have thought about the possibility of working. When my husband broke his leg, my elderly father-in-law looked for a job but couldn't find. My children were too young to work. So, the only way we could survive was for me to work. 1 found cleaning jobs with the help of my sister's elder brother-in-law, who has lived in the city for 10 years. After my husband's recovery I continued to work.

Another working married woman, Nurcan, 37, described her husband's initial resistance:

At first, when I raised the idea of working, he [her husband] refused and told me not even to dare think about it. Once, when I insisted, he beat me very badly and said that I was not to bring new rules to the old village, so I shut up. However, over time, the days that he could find work decreased. He was exhausted from looking for work and returning home empty-handed. On one of those days, he said we could look for a good house for me to work in as a cleaner. This is how 1 started working.

Not all males agree to the mobilization of female labor, and among those who do, the terms of this agreement differ. Some men accept their wives' working, whereas others only permit their daughter's employment. Esma, 23, stated that her father allowed her to work as a cleaner until she was engaged. After her engagement, the decision was left to her fiancé, who did not allow her to continue to work. Regardless of whether it was the father or the husband who made the decision, none of the young workingwomen had control over their own wages, nor did they contribute to the decisions about how their earnings would be spent. Rather, their earnings were

35 For Indonesia, see, Wolf, Factory Daughters. For Malaysia, see, Ong, Spirits of Resistance and Capitalist Discipline. 
directly controlled by their fathers, husbands or brothers. Gülsün, 17, who worked as a child caretaker for three months, explained: "My father asked different people whom he knew in Diyarbakır to find a good family for me to work for. He bargained with the family, and he took my wages."

In Diyarbakır, there are limited opportunities for women's employment, mainly as childcare workers, domestic laborers or unskilled labor in catering or small manufacturing. But more importantly, men found it more acceptable for women to be employed as a childcare worker or housecleaner than to work in a public area such as a restaurant or factory. Some of the interviewees explained this difference in the acceptability of jobs as being related to men's fear of gossip about the "reputation" of the women. In order to understand the reasons behind the perceptions of men regarding the suitability of a job for a woman, we should bear in mind the cultural patterns in Southeast Anatolia. In this region, cultural boundaries - of female activity are highly governed by prevailing tribal rules and customs (töre). As one of the traditional administrative structures, the tribal system still preserves some of its importance in people's lives. ${ }^{36}$ Tribal membership is considered to be a cultural identity based on an extended kinship network within which some traditional duties and rights prevail. ${ }^{37}$ In this hierarchy of authority, the male family members are defined as the guardians/protectors of women's honor, which is regarded as family honor. The notion of family honor is the basis of the power of fathers, brothers, uncles and male cousins over women. Not only male family members, but elderly women, too, enjoy power over younger women. Any act that undercuts the family honor is punishable by the male members of the family. ${ }^{38}$ Cultural mechanisms for circumscribing female movement and power in Diyarbakır seldom constrain older women. A woman's status will increase after giving birth to a male child and continue to increase as they age. In other words, the hierarchy among women is determined by age and motherhood. As Kandiyoti points out, women

36 Yalçın-Heckmann defines the țribe as "the community which believes that they are relatives, have mutual responsibilities towards each other and share a joint ethical code" See, Lale YalçınHeckmann, "Aşiretli Kadın: Cöçer ve Yarı-Cöçer Toplumlarda Yeniden Üretim ve Cinsiyet Rolleri," in Kadın Bakıs Açısından 1980'ler Türkiye'sinde Kadınlar, ed. Şirin Tekeli (Istanbul: Iletişim, 1990).

37 Zekai Bakar, Leyla Şen, and Nazan Üstündağ, Karacadağ Köylerinde Sosyal Yapi, Tarım ve Doğal Kaynaklar (Diyarbakır: Sürdürülebilir Kırsal ve Kentsel Kalkınma Derneği, 2002), Mehmet Faraç, Töre Kiskacında Kadın (Istanbul: Cünizi Yayıncılık, 2002), Berrin Oktay-Yılmaz, "Geleneklerin Ardındaki Olümler: Töre Cinayetleri," Kadın Araşıırmalan Dergisi, no. 8 (2003), Lale Yalçın-Heckmann, "Kurdish Tribal Organization and Local Political Processes," in Turkish State, Turkish Society, ed. Andrew Finkel and Nükhet Sirman (London: Routledge, 1990).

38 TKV.GAP, GAP Bölgesinde Kadınn Statüsü ve Kalkınma Sürecine Entegrasyonu Araştırması (Ankara: T.C. Başbakanlık Güneydoğu Anadolu Projesi Bölge Kalkınma Idaresi Başkanlığı, 1994), YalçınHeckmann, "Aşiretli Kadın." 
reach the peak of their authority and status as mothers-in-law and/or at the post-menopause age.$^{39}$ Whereas the aging woman is respected, the fertile young woman is dominated.

Therefore, conflicts within the household as a result of young women's working outside the home are common. An important element in intrahousehold conflict is the increasing differentiation between the female members of the family, which is a result of a number of different factors. In Diyarbakır, although young women make a financial contribution to the household budget, they do not achieve prestige in the household or have control over their earnings. Conversely, their mothers complain about the increased self-assertiveness of working unmarried women and regard them as a new source of conflict in the family. Regarding this new dynamic at work in forced migrant households, Raziye shared her experience in the following words: "Before employment, my daughter talked to me about everything... We shared everything. But after she began to work, gradually, she stopped sharing things with me. She even dared to shout at me when I asked a simple question." Cemile, who had two working daughters, had a similar experience:

I am tired of everything. For the first time in my life, I feel that I am too dependent on the mercy of others. At first, we suffered, until my husband and two of my sons found jobs. Then my husband fell sick. I had to take care of him and the younger children. So, my daughters looked for work. First, my eldest daughter found a job in a textile shop; then the younger one found work. Their attitudes changed so much that I regretted the day my husband fell sick and the day my daughters found jobs... If I had the chance, I would not stay here one more day. God damn those who forced us to live in this hell!

As the mother of working daughters, Zelal and Hatay silently agreed with Cemile. Based on the common complaints of the mothers, we may surmise that there is an increasing feeling of alienation and differentiation between the mothers and their working daughters. The older women gave a variety of responses when asked about the changes in the attitudes of the workingwomen. Some said that the young women exhibited increased self-assertiveness and arrogance towards their mothers, were less communicative with other family members, behaved disrespectfully towards the young male members of the family, increased their demands to visit friends and were reluctant to help their mothers with housework.

39 Kandiyoti, Cariyeler, Bacilar, Yurttaşlar. 
However, the overriding concerns of the mothers had to do with the reputations of their working daughters. Cemile said: "If there is gossip about them [the workingwomen], this means the end of everything. It will be a dishonor for the family. They will lose any chance of marriage, and, God help us, become a serious problem for the men of the family." The same concern was shared by the older women of the community, who. claimed that these workingwomen were "bringing new rules to the old village, which can also affect other young women in the community." Based on these statements, it may be argued that the women had an interest in the continuation of the existing patriarchal order, which attaches to young women the lowest and most subservient position in the social order.

Intensified problems within households, particularly problems between mothers and their young working daughters create a situation in which the older women actively prevent the employment of the younger women. Roj stated: "One of my eldest daughter's friends found her a job, but I did not let her go. Instead, my husband and I begged the boss to give the job to my son. In the midst of all these problems in the city, I could not bear the arrogance of the girl to whom I give birth." Resmigül, 36, the mother of one daughter, said: "The bad manners of the husbands are one thing. On the other hand, I see the status of the girls who begin to work in the city. They are out of control... they have no respect for their mothers. I do not let my daughter work. Thank God, my husband and sons managed to find work and there is no need for my daughter to work."

The statements young unmarried women made regarding their mothers supported the mothers' claims about their daughters' aggressiveness. Not only do the young women's statements reveal a high degree of estrangement, they also challenge conventional gender roles. The unmarried workingwomen, while defining themselves as "breadwinners," regarded their mothers as nonproductive members of the household who "waste time in the house." The developing distance between the mothers and their working daughters seems to be related to changing roles of productivity in the urban setting. The daughters, who were nothing more than "silent maids" charged with their mothers' domestic work back in the village, were able to access the labor market in the new urban environment. Yearning at once for the rural life and their associated productive roles, the older women resist the new dynamic of wage-earning daughters who have access to the labor market by attempting to place restrictions upon them. In turn, unmarried workingwomen resent the older generation of women as the hidden force behind the increased aggressiveness of male household members. Zekiye's words exemplify this attitude: 
If it were not for my mother, my brother would not be so violent. My mother encourages my brother by saying "her tongue is so long [she replies back to me] that she would be out of control if you were not here." I know her problem... she cannot accept that I am working. But this is not my choice. They decided that I should work. She wants me to be a silent maid to do her domestic work.

Hayrünisa, a 19-year-old woman working in a small textile workshop, said: "Before I started work, my mother and my brother had problems. My mother complained about my brother a lot. But now things have changed. My mother never argues with my brother. Their major topic of conversation is about how I have changed and how they must keep me under control." The increased pressure from male household members was justified in terms of the women's reputation and honor. Gülsün, 17, who worked as a childcare worker for three months, said:

After I started working, the behavior of my male relatives changed radically. Not only my brother, but my male cousins, too, followed me from time to time to check whether I came directly home. Recently, the lady of the house where I worked gave me an old dress of hers. When I wore it, my brother and my cousin beat me, saying I would become a prostitute if I went on acting like that.

In cases where the brothers are unemployed, their oppression over their sisters increase. Though the male household members justified their oppression by using the sensitive issue of the female's reputation and honor, their real concern appears to be with the challenge their working sisters pose to the conventional male role as breadwinners. Hayrünisa stated that she suffered a lot as a result of her brother's behavior:

I have three older brothers. One of them is mentally ill. My eldest brother is married. He is kinder to me than the younger one who, after he lost his job on a construction site, became my nightmare. Everyday when I came home, he was waiting for me and without any reason swore and slapped my face. When my older brother interfered, my younger brother claimed that his actions were to save the honor of the family. Once he beat me to such an extent that I could not go to work for two days. I am glad that he is in Istanbul now. I hope he will never come back.

Although allowed by their families to work as a last resort, young women are denied access to available opportunities such as skill-building courses 
or short-term vocational training that would contribute to their well-being. For example, Kader regretted that, "when the owner of the shop offered to enroll me in a free, short-term course to improve my skills, my family even threatened to remove me from the job; for them I work only on a temporary basis until my brother finds a job, so it is not necessary to improve myself." Hayrunisa and Aynur also stated that if their families had the chance, they would not let them go to other parts of the city for work, but "would prefer our working in the house or in the neighborhood."

Denying the young women access to available opportunities is a different aspect of deprivation by which family members can prevent workingwomen from attaining a better bargaining position and the power to change existing relations that would enable them to live according to their own wishes in the future. This denial of opportunities can be interpreted as co-operation between family members in response to a situation that they consider a challenge to their authority within the family. The result is a widening gap between the young workingwomen and the other family members, particularly the older women. When young women work outside of home, mothers reproduce patriarchy within the households and attempt to keep their daughters dependent and obedient by collaborating with the young male family members, reminding them of their traditional roles of protecting and dominating their sisters. Thus, young workingwomen in IDP households are a long way from "the bargaining stage" that would enable them to negotiate a changed role within the family.

\section{"Cooperative conflict" and perceptions of women's roles in IDP households}

The findings of my fieldwork in Diyarbakır support Sen's conceptualization of the household as a unit of "cooperative conflict." The mobilization of the female labor force can be assessed as a cooperative act on the part of the household to "add to the total availabilities of the household." 40 However, as Sen suggests, in households where women work outside, this cooperation coexists with extensive conflict. This is certainly the case in the IDP households studied in Diyarbakır. Moreover, Sen's bargaining model suggests that whether or not women will be empowered and to what extent they can deploy their bargaining power and negotiate their rights and roles depend on the nature of intra-household relations. What people can positively achieve is influenced by the enabling conditions of encouragement and cultivation of initiatives. ${ }^{41}$ If

40 Sen, "Cender and Cooperative Conflicts."

41 Jo Rowlands, Questioning Empowerment: Working with Women in Honduras (Oxford: Oxfam, 1997). 
encouragement and cultivation of initiatives are restrained, the bargaining power and opportunities will also be restricted. In the IDP communities, the household members are not supportive of workingwomen, and thus the latter group's opportunities to increase their bargaining power are limited.

A number of elements are at work in this restraint. First of all, wage earning for women is a new factor for these families. The reaction of IDP households to the employment of women varies according to the structure and dynamics of the household and includes violence, prohibitions and refusal to discuss the issue. Men take a conservative stance, retaining control of where women work and denying them access to their earnings. This appears to be an attempt by men to retain their conventional roles as guardian and protector of the subordinated and dependent female, as well as a response to the challenge women's working poses to the traditional male role of breadwinner. The increased aggressiveness and violence on the part of the men of the household can be regarded as the expression of their anxiety vis-à-vis the changing role of the women of the household.

Importantly, the findings of this study suggest that it is not just the attitudes and concerns of the dominating sex that disempower young women, but that the concerns and expectations regarding their own status lead older women, as well, to take an active part in their repression. The conflicting nature of relations among unmarried workingwomen and older women of the household is strongly tied to the status granted to older women by the age axis of the existing patriarchal norms, which create asymmetric power relations and shape the intra-household authority structure. Regarding the younger women's entry into the labor market as a challenge to the structured hierarchy within the household, the older women cooperate with men to promote an environment that intensifies the younger women's disenfranchisement from available resources and opportunities. This systematic denial of resources prevents young women's empowerment within the household and the community, as it weakens their bargaining power vis-à-vis the other members.

As Sen argues, the cooperative format calls for attention to perceptions in respect to interests, contributions and claims. The statements of workingwomen suggest that they experience improved well-being in terms of "functionings" - in this case, participation in the labor market, being the "breadwinner" and contributing to the well-being of the household. The most challenging aspect of the perceptions about the workingwomen is the notion of "breadwinner." This is partly related to the fact that "women's labor - whether paid or unpaid - is conflated with social and gender identity and with membership in social groups such as the 
family." 42 In a similar vein, Sen also points out the importance of the "form" of women's earnings. When women's earnings do not challenge the conventional role of "caretaker," then workingwomen do not face problems within the family. ${ }^{43}$

In the case of young workingwomen in IDP households in Diyarbakır, we observe the reverse side of this process. The perceptions young workingwomen in Diyarbakır have of themselves as "breadwinners" play a crucial role, especially in their estrangement from their mothers, whom they regard as nonproductive members of the household who "waste time in the house." Their attack on the social identity of older women as caretakers engaged in housewifery and motherhood is the reason behind the collective resistance young workingwomen face from the other household members.

My fieldwork showed similarities and differences between the experiences of poverty of young workingwomen and older women. As women, regardless of their age or marital status, they suffered from increases in the inequality of resource distribution within the household, including food, and access to basic services such as healthcare. However, in spite of these common experiences associated with the feminization of poverty, it is not possible to conclude that women are a homogenous group; rather, they are a heterogeneous group, with conflicting interests. The existence of these conflicting interests sheds light on the differences in how poverty is experienced. In comparison to the young women, the dignity of the older women is increasingly challenged in the new urban context, as they are the ones blamed for not efficiently fulfilling their conventional gender role as "caretakers." The married women complained of getting the brunt of disrespectfulness and humiliation from their husbands, parents-in-law and working daughters. Complaints regarding their daughters were focused on a common point - "Our daughters no longer show us respect"- and this was regarded as "unbearable."

Like their mothers, young workingwomen experienced reduced access to food and healthcare in the new urban context; in addition, however, they were also deprived of education/training, which limited the possibility for better work in the future, as well as a "voice" over matters concerning themselves and their households. They were discouraged from selfexpression, prevented from participating in decision-making processes, and their contribution to the family economy was devalued. All these factors diminished the possibility of the younger women's empowerment

42 White, Money Makes Us Relatives, 6.

43 Sen, "Gender and Cooperative Conflicts." 
within the family and the community. More than the older women, whose social context is limited to their communities, work brings young women increasingly under the control and pressure of their families and communities. As explained by the older women, any gossip about the reputation of the younger women brings shame on the family and may even endanger their lives.

The conflicting nature of the relationships and difficulties that young workingwomen face inside the household indicates that their employment cannot be considered a constructive strategy decided upon by the household as a response to increasing poverty. The frequent assumption regarding household strategies is that they are made at the household level, or, at the very least, are guided by parents concerned with household survival. However, the responses of the women in this study indicated that sending women outside the house to work was only a last resort, rather than a choice from a range of options. In the context of displacement, which is characterized by uncertainty and confusion, the ability for the IDP household to develop a survival strategy is difficult and limited. Instead, the decision to utilize female labor seems to be less a tactical mechanism and more a spontaneous development arising in the midst of poverty and misery.

\section{Conclusion}

The findings of this study suggest that the relationships among women in displaced households have a conflicting character. Unfortunately, current poverty line definitions and poverty mitigation/alleviation schemes to a great extent ignore household dynamics that affect intra-household resource distribution and how they lead to differentiated experiences of poverty within the same household. Although a wide range of work on dynamics within poor families exists, the complex nature of relations within the subordinated gender has been largely neglected, resulting in an ineffective use of available resources and failing palliative initiatives that cannot touch the main reasons for poverty and deprivation. The multidimensional nature of poverty necessitates a revision in these definitions and schemes that pays heed to the complex dynamics at play between and within gender and age groups in the household.

The context-specific approach can be an effective means in addressing the deficiencies of existing definitions of poverty and schemes to alleviate it. A wider, in-depth examination of the dynamics between the members in poor households is a required step in the context-specific approach. Instead of considering poor households as homogenous units, this approach requires sensitivity to the needs and expectations of the household 
members, not in such broad categorical terms as "male" and "female," but rather, according to the structured hierarchy shaped by the prevailing values within the household. As seen in this case study, values are crucial determinants of the structured hierarchy within the household, governing the relationships between household members and determining both the status of members and the allocation of resources within the household.

The context-specific approach must also be sensitive to the needs and new dynamics emerging as a result of extraordinary conditions and circumstances such as displacement, which result in sudden, extreme poverty and deprivation of households. Studies undertaken in the field underline the fact that IDPs must cope with serious problems and are often unprepared to make well-thought and strategic choices to mitigate their increasing poverty. These problems must be recognized by local, regional and national policymakers, who, in cooperation with grassroots NGOs, need to address the wider issues of poverty and deprivation. Poverty mitigation/alleviation schemes aimed at IDPs must take into account the experiences, needs and expectations of the community members, without undermining the fact that they are not homogenous. This approach, undertaken with the help of field surveys, can be an initial step in the diagnosis of the real situation of the members of IDP households.

From the initial strategy-building stage, poverty mitigation/alleviation schemes must involve all members of IDP households, avoiding the domination of high-status household members in needs assessments. Women's inclusion in strategy building is crucial; they must be encouraged to voice their own opinions, concerns and expectations in regard to the provision of services within the framework of any proposed program. Moreover, participation of women of all age groups, both employed and unemployed, is essential in order to avoid the reproduction of patriarchy and the increased feminization of poverty among the younger generation of women.

Services such as social skill-building and income-generating activities for women in displaced households should not limit their objectives to the creation of employment for women. Rather, in order to break the cycle of poverty, implementers of poverty mitigation/alleviation schemes must develop mechanisms that ensure that the women beneficiaries have control over their earnings and participation in decision-making processes. The mechanisms developed should be arenas of pluralistic decision-making that offer a voice to everyone, regardless of sex and age. These mechanisms must be sustainable, which can only truly be possible if IDPs take ownership of these mechanisms and internalize the pluralistic decisionmaking practices they employ. 
Inevitably, realization of this is a long-term goal that would involve a process of change and education. It also necessitates active planning that is sensitive to the dynamics of each household, rather than an overgeneralized and categorical definition of the beneficiaries. This is true not only for services provided to IDPs, but for any poverty mitigation/alleviation scheme developed for poor households. If household dynamics are not taken into consideration, poverty mitigation/alleviation schemes will only add to the "wealth and power gaps" between household members, which will in turn lead to increased conflict within the family and mitigate against the success of the household in developing strategies to escape from the poverty trap.

At the time I undertook this field study, the older women acted in cooperation with male household members to weaken the possibility of empowerment of young workingwomen. However, the complicated household dynamics made it difficult to predict how this process would play out in the future. Further studies about the current situation would provide insights into how intra-household conflicts have unfolded in the intervening period.

\section{References}

Alpar, Istiklal, and Samira Yener. Cecekondu Araştırması. Ankara: The Directorate of Social Planning Publication, 1991.

Ayata, Sencer. Kentsel Enformal Sektörde istihdam ve is Potansiyelinin Gelistirilmesi: Diyarbakır Alan Araştırmasi: UNDP, 2002.

Bakar, Zekai, Leyla Şen, and Nazan Üstündağ. Karacadağ Köplerinde Sosyal Yapi, Tarmm ve Doğal Kaynaklar. Diyarbakır: Sürdürülebilir Kırsal ve Kentsel Kalkınma Derneği, 2002.

Barut, Mehmet. "Çocuk ve Kadın Boyutuyla Gobçün Sosyolojik Açıdan Değerlendirilmesi." In Cö̧ Konferansı. Istanbul: Kırmızı Reklam Yayıncılık, 2004.

Bolak, Hale C. "Marital Power Dynamics: Women Providers and Working-Class Households in Istanbul." In Cities in the Developing World, edited by Josef Gugler, 218-32. New York: Oxford University Press, 1997.

Buchmann, Claudia. "Family Structure, Parental Perceptions and Child Labor in Kenya: What Factors Determine Who Is Enrolled in School?" Social Forces 78, no. 4 (2000): 1349.78.

Chant, Sylvia. Women and Survival in Mexican Cities. Manchester: Manchester University Press, 1991.

Cinar, Mine. "Unskilled Urban Migrant Women and Disguised Employment: Home-Workingwomen in Istanbul, Turkey." World Development 22, no. 3 (1994): 369-80.

Dağ, Rıfat, Atilla Cöktürk, and H. Cengiz Türksoy, eds. Bölgeiçi Zorunlu Gǫ̧̈ten Kaynaklanan Toplumsal Sorunların Dijarbakır Kenti Ölçeğinde Araştırılması. Ankara: TMMOB Yayınları, 1998.

De la Rocha, Mercedes, and Alejandro Grinspun. "Private Adjustments: Household, Crisis and Work." In Choices for the Poor. Lessons from National Poverty Strategies, edited by Alejandro Grinspun: UNDP, 2001.

Erder, Sema. "Köysüz 'Köylü' Göçü." Görüş, no. 34 (1998): 24-26.

__ "Yeni Kentliler ve Kentin Yeni Yoksulları." Toplum ve Bilim, no. 66 (1995): 107.19. 
Erman, Tahire, Sibel Kalaycıoğlu, and Helga Tılıç-Rittersberger. "Money Earning Activities and Empowerment of Rural Migrant Women in the City: The Case of Turkey." Women's Studies International Fonum 25, no. 4 (2002): 395-411.

Ersoy, Melih, and H. Tarık Şengül. Kente Gö̧̧ ve Yoksulluk: Diyarbakır Ömeği. Ankara: ODTÜ Kentsel Politika Planlaması ve Yerel Yönetimler Anabilim Dalı Yayınları, 2002.

Faraç, Mehmet. Töre Kıskacinda Kadın. Istanbul: Günizi Yayıncilık, 2002.

Feldman, Shelley. "Exploring Theories of Patriarchy: A Perspective from Contemporary Bangladesh." Joumal of Women in Culture and Society 26, no. 4 (2001): 1097-127.

Cöç-Der. Có̧̧ Edenlerin Sosyo-Ekonomik, Sosyo-Kültürel Durumlan, Gö̧̧ün Ortaya Çıkardığı Sorunlar, Askeri Çatışma ve Cerginlik Politikası Sonucu Yaşam Alanlannı Terk Eden Cö̧̧ Mağdurlannin Geri Dönüs Eğilimi Araștıması. Istanbul, 1999-2001.

Gökçe, Birsen, ed. Gecekondularda Ailelerarası Geleneksel Dapanışmanın Çăgdas Organizasyonlara Dönüşümü. Ankara: Başbakanlık Kadın ve Sosyal Hizmetler Müsteşarlığı Yayını, 1993.

Göktürk, Atilla. "Zorunlu Göç ve Bir Kent: Diyarbakır." In II. Ulusal Sosyoloji Kongresi: Toplum ve Cö̧̧, 356. 67. Ankara: Sosyoloji Derneği Yayın No: 5, 1997.

Illkkaracan, Ipek. "Göç, Kadının Ekonomik Konumu ve Karar Mekanizmaları." iktisat Dergisi, no. 377 (1998): 62.67.

Kalaycıoğlu, Sibel, and Helga Tilıç-Rittersberger. Evimizdeki Cündelikçi Kadınlar. Istanbul: Su Yayınları, 2001.

Kandiyoti, Deniz. "Bargaining with Patriarchy." Gender al Society 2, no. 3 (1998): 274-90.

- Cariveler, Bacilar, Yurttaşar. Istanbul: Metis, 1997.

Moser, Caroline. "Asset Vulnerability Framework: Reassessing Urban Poverty Reduction Strategies." World Development 26, no. 1 (1998): 1.19.

OECD. DAC Guidelines on Poverty Reduction. Paris, 2001

Okojie, Christina E.E. "Women in the Rural Economy in Nigeria." In Women, Work and Gender Relations in Developing Countries: A Clobal Perspective, edited by Parvin Chorayshi and Claire Belanger, 57.74. Connecticut \& London: Greenwood Press, 1996.

Oktay-Yılmaz, Berrin. "Celeneklerin Ardındaki Olümler: Töre Cinayetleri." Kadın Araştırmalan Dergisi, no. 8 (2003): $69-83$.

Onat, Ümit. Gecekondu Kadınının Kente Ozgü Düsünce ve Davranıslar Gelişstirme Süreci. Ankara: Başbakanlık Kadın ve Sosyal Hizmetler Müsteşarlığı Yayınları, 1993.

Ong. Aihwa. Spirits of Resistance and Capitalist Discipline: Factory Women in Malaysia. Albany: State University of New York Press, 1987.

Ozer, Ahmet. "Cüneydoğu'da Kentleşeme(me) Dramı." Cönüs, no. 34 (1998): 36-39.

Rowlands, Jo. Questioning Empowerment: Working with Women in Honduras. Oxford: Oxfam, 1997.

Sen, Amartya. "Cender and Cooperative Conflicts." In Persistent Inequalities, edited by Irene Tinker. Oxford: Oxford University Press, 1990.

Sevgi, Cezmi. Kentleşme Sürecinde lzmir ve Gecekondular. Izmir: Izmir Konäk Belediyesi Kültür Hizmetleri, 1988.

Sirman, Nükhet. "The Constitution of Relations between Strangers in Turkey." Paper presented at the SSRC the Beirut Conference on Public Spheres, 22-24 October 2004.

"Friend and Foe? Forging Alliances with Other Women in a Village of Western Turkey." In Women in Modern Turkish Society: A Reader, edited by Şirin Tekeli. New Jersey: Zed, 1995.

Şenyapıl,, Tansı. Gecekondu: Çeure isşilerin Mekanı. Ankara: Middle East Technical University, 1981.

TKV-GAP. GAP Bölgesinde Kadının Statüsü ve Kalkınma Sürecine Entegrasyonu Araştırması. Ankara: T.C. Başbakanlık Güneydoğu Anadolu Projesi Bölge Kalkınma Ídaresi Başkanlığı, 1994. 
TKV. "Unpublished Household-Level Survey among Migrant Families in Diyarbakır." 1996.

Türkyılmaz, Ahmet, Abdülhalik Çay, Zakir Avşar, and Mustafa Aksoy. Doğu ve Güneydoğu Anadolu'dan Terör Nedeniple Gö̧̧eden Ailelerin Sorunlan. Ankara: Başbakanlık Aile Araştıma Kurumu Başkanlı̆̆ı Yayınları No 115, 1998.

UN. Guiding Principles on Internal Displacement. New York, 1998.

Walby, Sylvia. Patriarchy at Work. Cambridge: Polity, 1986.

White, Jenny B. Money Makes Us Relatives: Women's Labor in Urban Turkey. Texas: University of Texas Press, 1994.

Wolf, Diane. Factor Daughters: Gender, Household Dynamics and Rural Industrialization in Java. Berkeley: University of California Press, 1992.

Yalçın-Heckmann, Lale. "Aşiretli Kadın: Göçer ve Yarı-Göçer Toplumlarda Yeniden Üretim ve Cinsiyet Rolleri." In Kadın Bakıs Açısından 1980'ler Türkiye'sinde Kadınlar, edited by Şirin Tekeli. Istanbul: Iletişim, 1990.

"Kurdish Tribal Organization and Local Political Processes." In Turkish State, Turkish Society, edited by Andrew Finkel and Nükhet Sirman. London: Routledge, 1990.

2002 Yılı Hanehalkı Bütçe Anketi. Ankara: State Institute of Statistics, 2003.

2003 Yilı Hanehalkı Bütçe Anketi. Ankara: State Institute of Statistics, 2004. 